\title{
APARTHEID SOUTH AFRICA'S NUCLEAR WEAPONS PROGRAMME AND ITS IMPACT ON SOUTHERN AFRICA
}

\author{
Jo-Ansie van $\mathrm{W}_{\mathrm{yk}}{ }^{1}$
}

Apartheid South Africa's nuclear related activities in Southern Africa have a long history. Apart from, inter alia, the development and existence of at least six nuclear devices (which was denied for decades), South Africa operated a nuclear test site in the Kalahari Desert on the border of Botswana, utilised uranium from Southwest Africa (now independent Namibia), and employed a nuclear deterrent strategy in response to Soviet support for Angola and liberation movements in the region. This elicited responses from the so-called Frontline States (FLS) as well as the members of the Southern African Development Community (SADCC). Therefore, the purpose of this contribution is to determine the extent of South Africa's nuclear activities as well as its impact on the region from the mid-1970s until 1991. This period covers the period since the Portuguese regime's collapse in 1974 and its domino effect in Southern Africa, the disintegration of the Soviet Union and the termination of the Cold War.

\section{Apartheid and the region}

Fueled by white nationalism, and international condemnation and isolation the National Party (NP) government in South Africa became convinced that white

${ }^{1}$ Lectures International Politics at the University of South Africa (Unisa), Pretoria, South Africa. Email:vwykjak@unisa.ac.za. 
rule in Southern Africa is threatened by African liberation movements supported by the Soviet Union and Cuba. South African-led excursions into Angola from Southwest Africa increased towards the end of the 1960s and, with South Africa's support for Ian Smith's government in Rhodesia, by the early 1970s marked new frontiers in South Africa's efforts to maintain white rule in the region. In an effort to establish links with other African states to counter support for the pro-Soviet liberation South African movements, Prime Minister John Vorster's "uitwaartse beleid" (outward movement policy) of accommodation and diplomacy or détente commenced in the early 1970s (Wallensteen 1971, 85-99). The purpose of Vorster's détente was to convince states in Southern Africa that South Africa's apartheid policies is not a threat to regional stability. However, Vorster's initiatives were short-lived.

Portuguese colonialism in Africa ended in 1974 with the military coup d'état in Portugal on 25 April 1974. One of the immediate consequences of the coup was that the so-called 'buffer states' between South Africa and the rest of black-ruled Africa was under grave threat with the independence of Angola and Mozambique, and developments in Rhodesia. Cuban support to the Movimento Popular de Libertação de Angola (MPLA) secured the movement's victory in Angola. Newly-independent Mozambique under the leadership of Frente de Libertação de Moçambigue (FRELIMO) signed a cooperation agreement with the Soviet Union. For South Africa, this created new insecurities on its borders (including Southwest Africa's) as Marxist and Communist liberation movements took over the governments of these countries (Saunders and Onslow $2009,225)$. In an effort to stem what was regarded as a communist threat to South Africa, the country intervened militarily in Angola in 1975.

From the mid-1970s, conflicts in Southern Africa were predominantly the result of the ideological rifts between the Cold War superpowers, namely the United States of America (U.S.) and the Soviet Union. The perception of white minority governments in South Africa and Rhodesia was that the Soviet Union's support for black liberation movements increased the Communist threats to these white regimes. These threat perceptions became the justification for, amongst others, cross-border military actions against countries supporting the liberation movements. With Soviet support for liberation movements and governments in Southern Africa, the South African 
government realised that it will have to counter the influence of this nuclear Goliath in the region.

In an effort to stem the perceived tide of communism in the region, South Africa retreated into a nuclear laager in South Africa ${ }^{2}$. The next section outlines the establishment and development of South Africa's nuclear weapons programme before proceeding to the country's regional policy. Thereafter, the article addresses three cases studies (Angola, Botswana and Southwest Africa) to illustrate the impact of South Africa's nuclear weapons programme on the region.

\section{The Nuclear laager}

South Africa's interest in the development of nuclear energy can be traced as far back as the 1940s. South Africa has one of the largest uranium reserves in the word. Uranium exploitation commenced in 1950 when the Anglo-American agency, the Combined Development Agency, installed equipment in South African mines to produce uranium oxide (Väyrynen 1977, 35). South Africa started to supply uranium to the UK and the US from 1953. By the mid-1970s, South Africa maintained a major position in terms of its known uranium resources (see Table 1).

One of the significant events in this process was Prime Minister Hendrik Verwoerd's inauguration of the first nuclear reactor on the African continent, the South African Fundamental Atomic Research Installation-1 (SAFARI-1), in 1965; a few years after the banning of the African National Congress (ANC). Whereas South Africa continued its stance on its preference for the peaceful uses of nuclear energy, Verwoerd's domestic policies soon became a matter of international concern. His government's emphasis on apartheid soon resulted in the country's international condemnation and eventually isolation.

In 1970, Prime Minister John Vorster announced that the Atomic Energy Board (AEB) of South Africa has developed a new uranium enrichment

${ }^{2}$ A laager is an enclosure and a reference to the positioning of ox wagons during the Great Trek in order to enhance safety. 
process. Although Vorster maintained that the aims of the South African nuclear programme is for peaceful uses such as power generation but that South Africa would not be limited to the promotion of the peaceful uses of nuclear energy.

Table 1: Estimated world resources of uranium (January 1975)

\begin{tabular}{|l|l|l|}
\hline Country & $\begin{array}{l}\text { Reasonably assured reserves } \\
\text { (RARs) } \\
\left({ }^{\circ} 000 \text { tonnes }\right)\end{array}$ & $\begin{array}{l}\text { Estimated } \\
\text { reserves } \\
\text { ('000 tonnes })\end{array}$ \\
\hline US & 320 & 500 \\
\hline Australia & 243 & 80 \\
\hline South Africa & 186 & 6 \\
\hline Canada & 144 & 324 \\
\hline Niger & 40 & 20 \\
\hline France & 37 & 25 \\
\hline Gabon & 20 & 5 \\
\hline Others & 80 & 35 \\
\hline
\end{tabular}

Source: Väyrynen $(1977,36)$

By 1976, South Africa's first uranium enrichment plant, Valindaba, was completed with the assistance of West Germany (Väyrynen 1977, 40). Although South Africa's nuclear explosives programme was "officially still aimed at peaceful uses until about 1977 ...the emphasis changed officially to a strategic deterrent capability" (Stumpf 1995) once the NP government's threat perception increased, the Border War escalated and violent control of domestic democratic forces further increased the country. As an adjunct of this shift in April 1978, Prime Minister John Vorster approved a three-phased deterrent strategy for South Africa (see Figure 1).

More pertinent were the results of the South African nuclear weapons programme that underpinned the deterrent strategy. Although denied for decades, the programme produced significant results. The first South African device was completed in 1978 with more devices completed at an 'orderly pace of less than one per year' (Stumpf 1995). The first aircraft-deliverable vehicle was completed in 1982 and eventually six 'nuclear devices' were produced (De Klerk 1993). 


\section{South Africa's regional policy}

By 1977, South Africa's defence spending has increased by $21.3 \%$; amounting to 18\% of the total budget (BETTS, 1979: 97) in the wake of the implementation of the UN's mandatory arms embargo in 1977. South Africa's regional policy of destabilisation and its nuclear weapons programme elicited various responses from countries in the region. These responses ranged from diplomatic engagement to diplomatic isolation (as a result of, inter alia, Organisation of African Unity (OAU) and UN sanctions). In addition to this, responses also included government support for liberation movements fighting against the NP government in South Africa.

Figure 1: South Africa's three-phased nuclear deterrent strategy:

\section{Phase 1}

Strategic uncertainty in which nuclear deterrent capability will not be acknowledged or denied.

\section{Phase 2}

Should South Africa be threatened by Warsaw Pact countries through surrogate Cuban forces in Angola, covert acknowledgement to certain international powers, e.g. the US would be contemplated.

\section{Phase 3}

In case partial disclosure does not result in the removal of the threat, public acknowledgement or demonstration by an underground test of South Africa's capability, would be considered.

Sources: De Klerk (1993) and Stumpf (1995).

South Africa's presence Southwest Africa has been discussed in great detail elsewhere. See, for example, Seiler (1982). South Africa's duplication of apartheid in the country was met with fierce domestic and international condemnation. South Africa has often been accused of the "illegal occupation" of Namibia (although it was then known as Southwest Africa) and the "illegal acquisition of Namibian uranium" (IAEA 1984, 1). For South Africa, the 
outcomes of the 1966 International Court of Justice (ICJ) case presented by Liberia and Ethiopia against the country were viewed as a justification for South Africa's involvement in Southwest Africa (Seiler 1982, 691).

\section{Botswana: "So far, and no further"}

Botswana shares a border with both South Africa and Namibia. Whereas Angola tested South Africa's aerial supremacy, landlocked and arid Botswana was in close proximity to South Africa's underground testing facility bordering on Southwest Africa, South Africa and Botswana. As part of South Africa's "Vreedsame Plofstof Projek" ('VP Projek' or the Peaceful Explosives Project), the Atomic Energy Board (AEB) acquired the farm Vastrap, north of the town Upington in the Kalahari Desert bordering on Botswana, in the 1970s as a demonstration site (Slabber 2012) ${ }^{3}$. The construction of the Vastrap Testing Range which included two test shafts (238m and $385 \mathrm{~m}$ deep respectively) and completed in 1976 and 1977 (Venter 2008, 205) went largely undetected ${ }^{4}$. A socalled cold test was scheduled for mid-1977 but prevented by unforeseen circumstances.

Shortly after this appointment as Minister of Foreign Affairs, Pik Botha received a visit by the America Ambassador to Pretoria in April 1977 (Botha 2008, 10). During the meeting, Ambassador Hepplethwaite, according to Botha, spread out "10-12 photographs" on his desk, asking Botha what the pictures "represented". Botha recognised it as a "large drill in an arid region [Kalahari Desert] digging a rather large hole". Botha realised that it was Soviet pictures forwarded to the Americans and undertook to discuss the matter with the Prime Minister. Vorster, according to Botha, was "upset". Warning of further international against South Africa, Botha and Vorster decided to complete the drilling and "remove all evidence".

With Pretoria's regional policies escalating in the mid-1970s, international attention on South Africa's nuclear ambitions was brought into sharp focus in August 1977 when a Soviet spy satellite, Cosmos 922, detected

\footnotetext{
${ }^{3}$ Johan Slabber joined the AEB in 1963 and the IAEA in 1994.

${ }^{4}$ Vastrap is an Afrikaans expressing meaning to dig in one's heels or standing one's ground.
} 
what appeared to be an underground nuclear test site in the Kalahari Desert (UN, 1991: 8). On 6 August 1977, Soviet president Leonid Brezhnev forwarded a message to US President Jimmy Carter about the Soviet Union's detection of what appeared to be a South African underground nuclear test site in the Kalahari. In an address to Parliament on 24 August 1977, Prime Minister Vorster went on to accuse the US, the UK, and Soviet Union of "blatant discrimination against South Africa" and accused the Soviet Union of "double standards" in accusing South Africa "of preparing a nuclear explosion" while itself is testing nuclear weapons. Vorster (in Barber and Barratt 1990, 241) then issued a stern warning: "If these things [accusations, double standards] continue and don't stop the time will arrive when South Africa will have no option, small as it is, to say to the world: So far, and no further, do your damndest if you so wish". In response to the international reaction (most notably by the US, the United Kingdom, French and West German governments) to the Soviet allegation and Prime Minister Vorster in a speech in Parliament, the South African Department of Foreign Affairs issued a confidential letter to all the South African Heads of Missions, confirming that it had "formally advised" the UK, U.S., German and French governments that:

South Africa does not have or intend to develop a nuclear explosive device for any purpose, peaceful, or otherwise. The so-called Kalahari facility is not a testing facility for nuclear explosions. There will not be any nuclear explosive testing of any kind in South Africa. (DFA 1977, 1)

South Africa was ill-prepared for the international reaction to the Kalahari Incident. In response to reports in the Washington Post, in a telegram - dated 31 August 1977 and captioned "TOP SECRET" on "South Africa and the bomb" - to the Secretary of Foreign Affairs, the South African Embassy in Washington, referred to the "flurry occasioned" by the event (South Africa $1977,1)^{5}$. The telegram also referred to US President Carter's comments in the Washington Post. The telegram stated that the effect of Carter's announcement

${ }^{5}$ At the time, Donald Sole served as South Africa's Ambassador to Washington. 
"has been to make the international community believe that South Africa has manufactured a nuclear device, which remains untested" (South Africa 1977, 1). The telegram concluded that "This undoubtedly implied a new watershed in South Africa's international relations. Nothing can be the same again, South Africa has become the seventh nuclear power even though it will not be recognised as such. Carter's statement [in the Washington Post] is a tacit confirmation of this" (South Africa 1977, 1). The telegram also stated that the "implications of this watershed in our foreign relations" is "too soon to assess" (South Africa 1977, 2). However, the telegram stated that South African can expect increased international condemnation and possibly Chapter VII sanctions against it; and that the US and USSR, with the support of Western Europe is viewed as "further proof of the extent of South Africa's isolation", and that South Africa was 'far more exposed than ever before in her history' (South Africa 1977, 2-3). The telegram concluded by suggesting that the whole situation could be "defused by a certain extent" if South Africa could show "to the world that the facility near Upington reportedly identified as a nuclear device testing ground if not in fact anything of the kind' (South Africa 1977, 4).

Pressurised by the US, South Africa is told not to make a commitment not to test nuclear devices. In an interview with the ABC News programme "Issues and Answers" in October 1977, Prime Minister Vorster denied that he gave any undertakings to President Carter that South Africa would not develop nuclear weapons (Rand Daily Mail 1977).

The detection of an underground nuclear test site in the Kalahari and the so-called "double flash" over the South Atlantic incident left no doubt that South Africa indeed had a nuclear weapons capability. For African states, these incidents confirmed South Africa's nuclear intentions on the continent (Saxena 1998). Therefore, several African states including Egypt and Nigeria embarked on a global campaign to force the South African government to dismantle its nuclear weapons programme and change its domestic policies. This campaign included diplomatic actions, UN sanctions and OAU resolutions against South Africa. While the majority of African states' rhetoric on a denuclearised Africa and post-apartheid South Africa continued unabated, a small number of African states embarked on the development of their own nuclear capability when Egypt, Libya and Nigeria commenced with nuclear development programmes in the mid-1970s (Oyebade 1998, 97). 


\section{The Groot Krokodil and the Total Onslaught}

P.W. Botha, called die Groot Krokodil (the Big Crocodile), was elected Prime Minister in 1978 and initiated the concept of a "total onslaught" against South Africa by the Soviet Union and its allies in the region. In response to this, Botha's government adopted the Total National Strategy. The decision to develop nuclear weapons was taken in 1978 by a small group of decision-makers who constituted the so-called Witvlei Committee. Chaired by Prime Minister P.W. Botha, the Witvlei Committee also included the Minister of Mining (F.W. de Klerk), the Minister of Foreign Affairs (Pik Botha), the Ministers of Finance and Defence, the chairman of Armscor (Commandant Marais), Dr Wally Grant (AEB) (succeeded by Dr. Wynand de Villiers), and the Director General of the Department of Foreign Affairs (DFA), Dr. Brand Fourie as secretary. Within a month of his election, Botha established a Cabinet committee to oversee the military aspects of nuclear devices. At a meeting of the Cabinet Committee on 31 October 1978, it was decided that Armscor, the Defence Force and the AEB should start to cooperate and prepare a top secret programme to initiate a nuclear weapons programme (Gould 2009, 91-93). This has resulted in a now declassified CIA $(1984,15)$ report observing that, since 1977, South Africa has followed a policy of "calculated ambiguity" with respect to its nuclear intentions by "intimating that it has the capability to produce nuclear weapons while disavowing any interest in doing so". Thus, South Africa embarked on the development of nuclear weapons as the 'ultimate defensive measure' (Saunders and Onslow 2009, 225) despite decades of public denials by the South African government.

By 1980, growing international condemnation and isolation had resulted in, amongst others, South Africa, despite a founder member, losing its seat on the Board of Governors of the International Atomic Energy Agency (IAEA) in 1977. This was followed by the rejection of the credentials of the South African delegation to the 1979 General Conference of the IAEA. South Africa's isolation was further entrenched by the fact that, since 1979 the UN Disarmament Commission kept the question of South Africa's nuclear capability on its annual agenda. Moreover, economic sanctions against South Africa had additional results. Whereas the country's uranium production peaked in 1980-1981 when it supplied 14\% of the world total, this figure 
decreased to $8 \%$ in 1989; in part due to the country's loss of the profitable Rössing uranium mine in Namibia, which produced an annual income of \$US 350 million for South Africa (UN 1991, 13).

Following more calls for South Africa to terminate apartheid and its nuclear weapons programme, and accede to the Treaty on the Non-Proliferation of Nuclear Weapons (NPT), the country maintained that it was not "in principle opposed to the NPT, provided that its basic requirements can be met" (DFA 1981). South Africa also stated that, despite it having not acceded to the NPT, has conducted its 'nuclear affairs' in line with the "spirit, principles and goals of the NPT" (DFA 1981). In addition to this, the South African government also indicated that, in the presence of a threat by the Soviet Union and its allies in the region and in the absence of UN support to South Africa, the country "cannot in the interest of its own security sign the NPT" (DFA 1981).

By 1980, the impact of South Africa's regional policy has resulted in major developments in the region and had been widely condemned. A study by the UN Secretary General released in 1980 concluded that the NP's policy of apartheid posed the "greatest threat" to peace in Southern Africa. The report concluded that "the greatest threat to peace in the region stems from a racist regime's denial of basic rights to the overwhelming majority of the population and its willingness to use strong repressive means, both internally and externally, to preserve its interests and privileges" (UN 1991). The report also cited possible reasons for South Africa's nuclear weapons programme, namely "as a deterrent or intimidatory instrument against neighbours; as an assertion of defiance and desperation (presumably a last resort device); and as a means of intimidating black South Africans and lessening the risk of internal unrest while boosting the morale of the beleaguered whites". The report also suggested that South Africa "rather than deploy or openly test nuclear weapons", the country "might seek to follow and exploit a policy of ambiguity of latent proliferation" (UN 1991).

In 1991, the UN, again, addressed South Africa's regional policy. It explained that South Africa's regional emphasis on coercion and threat' is deeply rooted in "a deep doubt about the prospects for the long-run viability" of apartheid. The UN declared that it is this "linkage" between the domestic regime and its strong-arm tactics regionally that characterized South Africa's 
relations wi.th its neighbours. In other words, South Africa's internal coercion was duplicated regionally (UN 1991, 38).

Although the Truth and Reconciliation Commission's (TRC) investigated South Africa's chemical and biological weapons programme, it did not investigate South Africa's nuclear weapons programme. This is an inherent flaw of the TRC's mandate, which was to investigate individual human rights abuses only. The extent of the impact of South Africa's regional policies is contained in the TRC's report on the amnesty applications of the security forces of the NP government. Covering the period 1960-1994, the TRC concluded that "the regions beyond South Africa's borders bore the brunt of the counterrevolutionary warfare waged by the South African security forces, including the police, the defence force and intelligence" (TRC 2003, 182).

Although only a total of 293 members of the apartheid security forces applied for amnesty, the extent of the country's regional policies are clearly illustrated in these few cases. Of the 293 members that applied for amnesty, only 31 served as members of the South African Defence Force (SADF). These 293 members applied for amnesty for a total of 550 incidents, which included 73 incidents outside South Africa. These external incidents occurred in Angola, Botswana, Lesotho, Mozambique, Southwest Africa/Namibia, Swaziland, Tanzania, the UK, Zambia, and Zimbabwe (TRC 2003, 182-191). Security forces' operation in these countries included, amongst others, killings, abductions, bombings and cross-border raids with the aim to destabilise countries supporting and/or hosting the South African liberation forces. The TRC, for example, received 114 applications for amnesty from members of the security forces involving 889 killings. As Table 2 indicates, a large number (684) of these killings took place outside South Africa.

Table 2: Killings by South African security forces outside South Africa

\begin{tabular}{|l|l|}
\hline Period & Number of killings \\
\hline $1970-1979$ & 627 \\
\hline $1980-1984$ & 13 \\
\hline $1985-1989$ & 44 \\
\hline Total & 684 \\
\hline
\end{tabular}

Source: TRC $(2003,192)$ 
South African security forces also conducted several cross-border raids in the region (see Table 3). Several cross-border abductions also took place. Of these, amnesty applications for 80 of these abductions were received; 17 of these took place outside South Africa (TRC 2003, 204-205).

Table 3: Cross-border raids by the South African security forces

\begin{tabular}{|c|c|c|}
\hline Date & City/Country & Security Force \\
\hline $\begin{array}{ll}30 & \text { January } \\
1981 & \\
\end{array}$ & Matola, Mozambique & $\begin{array}{ll}\text { SADF } & \text { Special } \\
\text { Forces } & \end{array}$ \\
\hline $\begin{array}{ll}9 & \text { December } \\
1982 & \end{array}$ & Maseru, Lesotho & $\begin{array}{ll}\text { SADF } & \text { Special } \\
\text { Forces } & \\
\end{array}$ \\
\hline 23 Мау 1983 & Matola, Mozambique & SAAF \\
\hline 14 June 1985 & Gaborone, Botswana & $\begin{array}{ll}\text { SADF } & \text { Special } \\
\text { Forces } & \\
\end{array}$ \\
\hline $\begin{array}{ll}19 & \text { December } \\
1985 & \end{array}$ & Maseru, Lesotho & Security Branch \\
\hline 19 Маy 1986 & $\begin{array}{l}\text { Botswana, Zambia \& Zimbabwe (the } \\
\text { so-called EPG Raids) }\end{array}$ & SADF \\
\hline April 1990 & $\begin{array}{l}\text { Botswana (the so-called Chand } \\
\text { Incident) }\end{array}$ & $\begin{array}{l}\text { Vlakplaas } \\
\text { operatives }\end{array}$ \\
\hline
\end{tabular}

Source: TRC $(2003,196 ; 220)$

In addition to these, other joint operations by Special Forces and Security Branch included the bombing of two houses in Mbabane, Swaziland, on 4 June 1980; the abduction from Swaziland, and subsequent torture of ANC member Dayan "Joe" Pillay on 19 May 1981; an attack on the home of Nat Serache in Gaborone (13 February 1985); a car bomb explosion which killed Vernon Nkadimeng (aka Rogers Mevi) on 14 May 1985 in Gaborone; a raid on Aubrey Mkhwanazi (aka Take Five) and Sadi Pule on 31 December 1986 in Gaborone; a car bomb which killed Mmaditsebe Phetolo and two children on 9 April 1987 in Gaborone (the so-called McKenzie car bomb); a bomb at the Oasis Motel in Gaborone which did not detonate but was intended for in August or September 1987; the Zimbabwe cell of the Civil Co-operation Bureau's (CCB) car bomb in Harare, Zimbabwe, on 11 January 1988 (the so-called Bulawayo Operation); a "hot pursuit" operation into Botswana after the "discovery" of an arms cache in Krugersdorp on 28 March 1988 (TRC 2003, 212-216). 


\section{Angola: Going ballistic" The rationale for nuclear-tipped ballistic missiles}

Angola is unique in Southern Africa in that it was both the theatre of battle for the conventional and Cold War in the region. Cuban and Soviet support for liberation movements such as the Southwest People's Organisation (SWAPO) and the ANC in the Angola fighting against the SADF culminated in a full-scale conventional war from mid-1970 to 1989 when Namibia became independent.

Once it became clear that parties to the Alvor Agreement in Angola the MPLA, the FNLA and UNITA - is not prepared to jointly govern Angola (after the Portuguese left the country) until 11 November 1975, the Portuguese governor gave in and gave precedence to the MPLA. In Angola, this resulted in a civil war with the MPLA (now in government) being assisted by Cuban troops to stabilise the country. Unita according to Pik Botha (then South Africa's Ambassador to Washington, U.S.) requested South Africa's assistance against the MPLA/Cuban offensive (Botha 2008, 2). In South Africa the question was: "where would the Cubans stop?" (Botha 2008, 2).

South Africa's missile development programme commenced in 1963 and resulted early in the manufacturing of the $22 \mathrm{~km}$-range Valkiri (a tactical surface-to-surface artillery rocket) and the 4-10km-range V3 Kukri (a tactical air-to-air missile) (UN 1991, 18). As South Africa's missile-related expertise improved, a missile test range was constructed in St. Lucia (close to the Mozambican border) in 1968. The NP government also commenced with the development of a single-stage, intermediate-range ballistic missile (IRBM), the first of what became known as the Republic of South Africa (RSA) missile series (see Table 4). This initiative formed part of a government-supported commercial space launch vehicle programme in the 1970 s with the assistance of, inter alia, Israel and Iraq (NTI 2009). Originally, the intended payload for these missiles was most likely to be the 'fission gun-type devices' developed in South Africa between 1971 and 1989 (Stumpf 1995).

In 1978, Kentron Missiles, a subsidiary of the state-owned Armscor was established as the country's dedicated missile manufacturer (NTI 2009) ${ }^{6}$. In

${ }^{6}$ While still in office, President de Klerk's government presided over the establishment of Armscor successor, Denel (Pty) Limited on 1 April 1992. 
1983, the South African government announced its intention to close the St. Lucia test range and constructed a new range, the Overberg Toetsbaan (OTB or Overberg Test Range) in the De Hoop Nature Reserve in the Overberg in the Western Cape. This development signaled a new era in South Africa's missile capabilities.

Table 4: South Africa's missile series

\begin{tabular}{|l|l|l|l|}
\hline $\begin{array}{l}\text { Name of } \\
\text { missile }\end{array}$ & Type mass & $\begin{array}{l}\text { Trajectory } \\
\mathbf{( k m )}\end{array}$ & $\begin{array}{l}\text { Warhead } \\
\mathbf{k g})\end{array}$ \\
\hline RSA-1 & $\begin{array}{l}\text { Intermediate range, single- } \\
\text { stage ballistic missile }\end{array}$ & 1100 & 1500 \\
\hline RSA-2 & $\begin{array}{l}\text { Intermediate range, single- } \\
\text { stage ballistic missile }\end{array}$ & 1900 & 1500 \\
\hline RSA-3 & $\begin{array}{l}\text { Solid-fuel orbital launch } \\
\text { vehicle }\end{array}$ & $\begin{array}{l}\text { Information } \\
\text { not available }\end{array}$ & $\begin{array}{l}\text { Information not } \\
\text { available }\end{array}$ \\
\hline RSA-4 & Solid-propellant & $\begin{array}{l}\text { Information } \\
\text { not available }\end{array}$ & 700 \\
\hline
\end{tabular}

Source: NTI (2010)

In 1978, Kentron Missiles, a subsidiary of the state-owned Armscor was established as the country's dedicated missile manufacturer (NTI 2009) ${ }^{7}$. In 1983, the South African government announced its intention to close the St. Lucia test range and constructed a new range, the Overberg Toetsbaan (OTB or Overberg Test Range) in the De Hoop Nature Reserve in the Overberg in the Western Cape. This development signaled a new era in South Africa's missile capabilities.

The decline in the relative strength of the South African Air Force (SAAF) in Angola in the early 1980s illustrated that the SADF required substantial support to counter Angolans' air superiority which included 140 Soviet tactical aircraft such as MiG-21, MiG-23 and Su-22. South Africa's Buccaneers, Mirage-III and Mirage F-1 were largely outnumbered and technologically inferior (UN 1991, 23). Feeling the impact of international arms

7 While still in office, President de Klerk's government presided over the establishment of Armscor successor, Denel (Pty) Limited on 1 April 1992. 
embargoes and the military might of the combined Angolan, Cuban and Soviet forces on the northern borders of Southwest Africa, the South African military establishment increased efforts to enhance the country's weapons capabilities to reduce casualties and to continue to counter the offensive against the country. This included expanding the country's nuclear capabilities. With the South Africa's regional dominance in the balance, the South African military establishment began to consider long-range missiles to secure the country's neighbourhood.

By the 1980s, according to Hannes Steyn (a former member of the Armscor Board); Richardt van der Walt (a former General Manager of the AEC); and Jan van Loggerenberg (a former Chief of the South African Air Force), South Africa's missile arsenal included, inter alia, air-to-air missiles and an anti-tank missile (Steyn, van der Walt and van Loggerenberg 2003, 54-55) ${ }^{8}$. The RSA-3 missile could have delivered a small warhead, and was most likely a space launch adaptation of the RSA-2 missile. In order to support its missile development programme, the NP-led South African government developed an indigenous solid-propellant production capability, the RSA-4 missile, which was developed when President de Klerk announced the dismantlement and destruction of South Africa's nuclear devices and, subsequently, its space programme. The RSA-4 missile may have been capable of delivering a $700 \mathrm{~kg}$ nuclear warhead from South Africa to any location in Southern Africa (Steyn, van der Walt and van Loggerenberg 2003, 54-55).

South Africa continued with its missile development programme and on 5 July 1989, two months before President De Klerk took office, successfully launched what the South African government called a "booster rocket" but what US intelligence sources called a missile from the OTB (UN 1991, 19; NTI 2009). According to the UN (1991, 25), the range of this rocket was $1450 \mathrm{~km}$. Toward the end of 1989 the Berlin Wall collapsed which, inter alia, ushered in the demise of the Soviet Union and the end of the Cold War. These events cascaded to Southern Africa with the independence of Namibia; the withdrawal

${ }^{8}$ Steyn, van der Walt and van Loggerenberg were closely involved in various aspects of the South African nuclear weapons programme. 
of Cuban troops from Angola; and the Soviet Union's departure from the region.

\section{Playing the regional card again: South Africa and the "accession dilemma"}

F.W. de Klerk became the Acting President on 15 August 1989 following the resignation of P.W. Botha on 14 August 1989 due to ill health. According to Pik Botha, he "intimated to De Klerk that the two top priorities awaiting us were the release of Mandela and the dismantling of our nuclear bombs. He agreed" (Botha 2008, 12; Botha 2010).

By September 1990, a written statement issued by Pik Botha was circulated at the 34th Regular Session of the IAEA GC. In the statement Botha indicated that South Africa was "prepared" to accede to the NPT, but with a caveat "in the context of an equal commitment by the other states in the Southern African region" (South Africa 1990, 2). Moreover, Botha also indicated that his government intended to commence talks with the IAEA on concluding a Safeguards Agreement with the Agency (South Africa 1990, 2). The South African diplomatic effort paid off: the IAEA Director General indicated that the Agency was ready to commence talks with South Africa "without delay" (UN 1991, 11).

The international community "anticipated" that South Africa's accession to the NPT would create a "favourable condition for other regional hold-outs to sign as well". These "regional hold-outs" included Algeria, Angola, Djibouti, Mauritania, Mozambique, Niger, Tanzania, Zambia and Zimbabwe. The UN added that, "in this way, joining the NPT would greatly strengthen South Africa's place in the international community and reinforce the Treaty" (UN 1991, 14). In March 1990, South Africa informed the NPT's repository states that it will accede to the NPT upon the condition that certain Frontline States make a similar commitment. De Klerk repeated this position in a letter to US President George HW Bush dated 31 August 1990. De Klerk mentioned that the Frontline States made South Africa's relinquishment of its nuclear weapons a condition for their accession to the NPT. De Klerk also indicated to Bush that South Africa intends to open "all" South facilities, irrespective if the country accedes to the NPT, in November 1991. De Klerk outlined the "dilemma that accession to the Treaty poses presently", i.e. the challenges 
associated with the country's political transition (De Klerk 1990). Furthermore, the "accession dilemma" means that De Klerk's government should not be seen as giving in to foreign demands in the initial phases of the country's transition. De Klerk also expressed his fears of the 'political exploitation' of South Africa's accession and suggests that an initiative by the three depository states should commence in order to broker Frontline States' accession to the NPT in order to "create the required context for South Africa to accede to the Treaty at the earliest possible date" (De Klerk 1990).

In June 1991, Pik Botha announced that the South Africa government intended to reverse its years of opposition to the NPT and sign the Treaty. At the time, the New York Times (21 March 1990) reported that the development that "appears to have swung South Africa around in favour of signing the treaty, officials say" was an assurance from the US, the UK and the USSR that "for procedural reasons" the IAEA:

[...] would not be in a position to start inspecting South Africa's plants for about two years after it signed. Britain also assured South Africa that if it signed the treaty, European countries were likely to lift their ban on nuclear cooperation with South Africa.

On 8 July 1991, the New York Times (9 July 1991) reported that Pik Botha had signed South Africa's accession to the NPT at a ceremony in Pretoria. This was later confirmed by the South African government and the IAEA.

\section{Conclusion}

In search for security and supremacy, South Africa left no stone unturned. In fact, it developed not one, but six nuclear devices to secure its protection (de Klerk 1993). Whereas South Africa employed a nuclear deterrent strategy since the 1970s, Pik Botha admitted that he was always convinced that South Africa would never used a nuclear weapon in the region but that its true value was that South Africa's nuclear weapons constituted a deterrence in the region. According to Botha: 
The SA [South African] military believed that was a powerful deterrent, and it should be kept, not as a battlefield weapon, but as a deterrent. The question was - particularly after the Angolan incursion - where would the Soviets stop? If they advanced in Angola, and then Botswana and Zimbabwe, the Witwatersrand industrial area would come within range of Soviet aircraft. This would be potentially disastrous for the security and survival of the SA [South African] state. Therefore atomic weapons could be used as a deterrent against this advance, and as a means to get western aid - along the lines of unless you help us, we will drop the bomb. Personally, I did not think this would work, or that atomic weapons would ever be used - and I believed that the West would realise this. South Africa had so much more to lose, if there was a nuclear exchange with the USSR. (Botha 2008, 11)

However, Botha has the luxury of hindsight which did not exist during the period under discussion. For South Africa's minority government, the threats to the country were real and required every effort to counter the spread of communism and all that threaten white rule. Therefore, the country employed several strategies for survival ranging from diplomatic efforts such as the "uitwaartse beleid" to intervention (Angola 1975), and cross-border raids, abductions and killings in Southern Africa. In addition to these, the country employed a nationalist ideology to defend the laager, garner support for its Border War and destabilization policies. Public efforts to garner nationalist sympathies were complemented with secrecy, delaying tactics and selective cooperation with states in Southern Africa and elsewhere. For countries in the region, the legacy of South Africa's apartheid policies may persist. What is clear is that the region's post-Cold War and post-apartheid ambitions to move towards closer unity remains elusive. 


\section{REFERENCES}

Barber, J., and J. Barratt. 1990. South Africa's foreign policy: the search for status and security, 1945-1988. Johannesburg: Southern Book Publishers.

Betts, R. K. 1979. "A diplomatic bomb for South Africa?" International Security 4(2): 91-115.

Botha, P. 2008. "Former South African Foreign Minister RF 'Pik' Botha in an interview with Dr Sue Onslow". Interview conceded on July 15. Accessed on May 2013: http://www2.lse.ac.uk/IDEAS/programmes/africaProgramme/pdfs/bot haInterview.pdf.

Botha, P. 2010. "Interview". In: From Verwoerd to Mandela. South African diplomats remember. Volume 3: Total onslaught to normalisation, compiled by P. Wolvaardt, T. Wheeler, and W. Scholtz. Johannesburg: Crink Publishing.

CIA. 1984. "Trends in South Africa's nuclear security policies and programs." National Intelligence Estimate. October 03.

De Klerk, F. W. 1990. “Letter to US President George H.W. Bush.” 31 August. Bush Presidential Library.

De Klerk, F. W. 1993. "Matters relating to nuclear non-proliferation treaty, violence, negotiation and the death penalty." Statement by the State President to a Joint Sitting of Parliament, 24 March. Hansard, col 3465-3478.

DFA. 1977. "To all Heads of Mission: South Africa nuclear bomb charges." August 26. Department of International Relations and Cooperation (DIRCO), Archive file 137/11 and 137/11/23, DIRCO, Pretoria.

DFA. 1981. "Directive for discussions of nuclear matters with United States authorities." 28 March. DIRCO Archive, Pretoria.

Gould, C. 2009. "The nuclear weapons history project". In Paper Wars: Access to information in South Africa, edited by K. Allen. Johannesburg: Wits University Press.

IAEA. 1984. "South Africa's nuclear capabilities." Resolutions adopted during the 266th plenary meeting on September 28, 1984. Accessed on April 22, 2013: http://www.iaea.org/. 
New York Times. 1990. "South Africa seen as ready to sign nuclear pact." March 21. Accessed on September 21, 2011: http://www.nytimes.com/1990/03/21/world/south-africa-seen-asready-to-sign-nuclearpact.html scp $=20 \& s q=$ SOUTH + AFRICA + NUCLEAR $\&$ st $=$ nyt.

New York Times. 1991. "South Africa signs a treaty allowing nuclear inspection." July 9. Accessed on September 21, 2011: http://www.nytimes.com/1991/07/09/world/south-africa-signs-atreaty-allowing-nuclearinspection.html?scp=15\&sq=SOUTH+AFRICA+NUCLEAR\&st=nyt NTI. 2009. "South Africa missile chronology." Accessed on April 19, 2012: http://www.nti.org/media/pdfs/south_africa_missile.pdf? =131646679 $\underline{1 .}$

NTI. 2010. South Africa profile: nuclear overview. January. Available at: http://www.nti.org/e_research/profiles/SAfrica/Nuclear/index.html. Accessed on: 9 April 2010.

Oyebade, A. 1998. "African security and nuclear weapons: past fears and future relevance." In: Africa after the Cold War. The changing perspectives on security, edited by A. Oyebade and A. Alao. Trenton: African World Press.

Rand Daily Mail. 1977. "PM tells when US turned against SA." October 03: 3. Saunders, C., and S. Onslow. 2009. "Cold War and Southern Africa, 1976-1990." In Cambridge History of the Cold War. Volume III, edited by A. Westad and M. Leffler. Cambridge: Cambridge University Press. Saxena, S.C. 1998. "Disarmament: the African perspective." Strategic Analysis XXII: 993-1017.

Seiler, J. 1982. "South Africa in Namibia: persistence, misperception, and ultimate failure." The Journal of Modern African Studies 20(4): 689712 .

Slabber, J. 2012. "South African weapons programme: Development of explosives." Presentation to the conference "Historical dimension of South Africa's nuclear programme', Monash South Africa, Pretoria, South Africa, December 9-12. 
Steyn, H., R. van der Walt, and J. van Loggerenberg. 2003. Armament and disarmament. South Africa's nuclear weapons experience. Pretoria: Network Publishers.

Stumpf, W. 1995. "Birth and death of the South African nuclear weapons programme." Paper presented at the "50 years after Hiroshima' Conference, organised by USPID (Unione Scienziati per Disarmo), Castiglioncello, Italy, September 28 to October 02. Accessed on April 19, 2012: http://www.fas.org/nuke/guide/rsa/nuke/stumpf.htm.

South Africa (Embassy Washington). 1977. "South Africa and the bomb." Telegram No 273, August 31. DIRCO Archives, Pretoria.

South Africa (Government of). 1990. "Statement on South Africa's position on accession to the Nuclear Non-Proliferation Treaty." Statement conceded on September 17 at the International Atomic Energy Agency during the $34^{\text {th }}$ regular session of the General Conference. Communication received from South Africa. Accessed on May 06, 2013:

http://www.iaea.org/About/Policy/GC/GC34/GC34InfDocuments/Engl ish/gc34inf-290 en.pdf.

TRC. 2003. "The former South African government and its security forces." Volume 6, section 3, chapter 1. Accessed on May 06, 2013: http://www.info.gov.za/otherdocs/2003/trc/3_1.pdf.

United Nations. 1991. "South Africa's nuclear-tipped ballistic missile capability." Report of the Secretary General, A/45/571. New York: UN.

Väyrynen, R. 1977. "South Africa: a coming nuclear power?" Instant Research on Peace and Violence 7(1): 34-47.

Venter, A. J. 2008. How South Africa built six atomic bombs and then abandoned its nuclear weapons program. Kayalami Estate: Ashanti Publishing.

Wallensteen, P. 1971. "Dealing with the devil: five African states and South Africa." Instant Research on Peace and Violence 1(3): 85-99. 


\begin{abstract}
Apartheid South Africa's nuclear related activities in Southern Africa have a long history. Apart from, inter alia, the development and existence of at least six nuclear devices, South Africa operated a nuclear test site in the Kalahari Desert on the borders of Botswana, utilised uranium from Southwest Africa (now independent Namibia) as its Class C Mandate and employed a nuclear deterrent strategy in response to Soviet support for Angola and liberation movements in the region. This elicited responses from the so-called Frontline States as well as the members of the Southern African Development Community (SADCC). Therefore, the purpose of this intended contribution is to determine the extent of South Africa's nuclear activities as well as its impact on the region. Based on archival research, the article intends to make a contribution to the study of the region, the evolution of regional integration in Southern Africa and Cold War studies in Southern Africa.
\end{abstract}

\title{
KEYWORDS
}

South Africa; Southern Africa; Nuclear Weapons; Regional Impact. 